THE EFFECTIVENESS OF BLENDED LEARNING STRATEGY FORMULATION ON IMPLEMENTING CURRICULUM IN DEPARTMENT OF CURRICULUM AND EDUCATIONAL TECHNOLOGY AT PADANG STATE UNIVERSITY

THE EFFECTIVENESS OF BLENDED LEARNING STRATEGY FORMULATION ON IMPLEMENTING CURRICULUM IN DEPARTMENT OF CURRICULUM AND EDUCATIONAL TECHNOLOGY AT PADANG STATE UNIVERSITY

\author{
Alwen Bentri, Ulfia Rahmi \\ alwenbentri@gmail.com dan ulfia24@gmail.com \\ Jurusan Kurikulum dan Teknologi Pendidikan \\ Fakultas Ilmu Pendidikan \\ Universitas Negeri Padang
}




\title{
THE EFFECTIVENESS OF BLENDED LEARNING STRATEGY FORMULATION ON IMPLEMENTING CURRICULUM IN DEPARTMENT OF CURRICULUM AND EDUCATIONAL TECHNOLOGY AT PADANG STATE UNIVERSITY
}

\begin{abstract}
Abstrack
The purpose of this study was to test the effectiveness of formulation of blended learning validated and it's practicality was counted from previous study. The model used for the overall study was ADDIE model of the five stages, namely Analysis, Design, Development, Implementation, and Evaluation. This second year was the implementation phase to test the effectiveness of the formulation blended learning strategy on the School Curriculum Studies subjects. The activity began with implementing the learning process using blended learning strategy formulation with the formula of online learning and face-to-face $62.5 \% 37.5 \%$ applied to 40 students. Based on data analysis has been conducted on students' final grades obtained by the value of the $t$ test at the 0.05 level of 0.032 . This proved that there were significant differences between the results of learning to use the strategy formulation blended learning with face-to-face lectures on the implementation of the curriculum in the Department of Curriculum and Educational Technology. In other words, the strategy formulation of blended learning was more effective than lectures conducted by face-to-face. The implication of this study need to be formulated of combination formulations face to face and online learning based on the characteristics of lecture material.
\end{abstract}

Keyword: effectiveness, formulation, strategy, blended learning 


\section{THE EFFECTIVENESS OF BLENDED LEARNING STRATEGY FORMULATION ON IMPLEMENTING CURRICULUM IN DEPARTMENT OF CURRICULUM AND EDUCATIONAL TECHNOLOGY AT PADANG STATE UNIVERSITY}

\section{Introduction}

The Implementation of curriculum which lasts ideally should based on national standards of education in accordance with the Regulation number 32 in 2013 implemented since primary education, secondary to university. Implementation of effective curriculum also should be applied to all fields of study at each level of education to produce quality graduates. For the learning process follows the standard process, that education was held in an interactive, inspiring, fun, challenging, motivating learners to participate actively and provide enough space for innovation, creativity, and independence in accordance with their talents, interests, and physical and psychological development of learners..

One of the subjects in the Department of Curriculum and Educational Technology at the Faculty of Education is the School Curriculum Studies. Through this subject students are expected to know, understand and apply the concepts of curriculum studies at school. In lecturing process, students are expected to apply the concepts of curriculum and assessment as well as its analysis of the current curriculum. The curriculum analysis is focused on the curriculum 2006 and 2013 especially about the structure and the concepts of the curriculum.

In relation with this, the implementation of the curriculum is essential in the stages of education. According to Alwen (1993: 23) the learning activities are conducted in order to realize a curriculum that is still potential (written) into actual is the implementation of the curriculum. It can be said that the implementation of the curriculum is the result of the lecturer's translation toward curriculum as a written plan that is poured into students' learning experience in learning activities

When referring to regulation 32, 2013, the implementation of the curriculum in the practice is less interactive because in the process of implementation, there is a less situation that is expected as listed on the PP. These conditions need to be addressed by designing the concept of implementing the curriculum become a learning process that is interactive, inspiring, fun, challenging, motivating learners to participate actively and provide enough space for innovation, creativity, and independence in accordance with their talents, interests, and development Physical as well as psychological learners. Many collage facilities can be optimized their utilization, such as the Internet to create a learning atmosphere that is referred to above. Accordingly, in the first year of the study, researchers team develop and validate the strategy formulation of blended learning for the School Curriculum Studies subject in order to implemention curriculum in the department of Curriculum and Educational Technology FIP UNP. The blended learning strategy formulation is $62.5 \%$ of online learning and face-to-face lectures $37.5 \%$. In the second year, it followed by calculating and explaining the practicality of the formulation

Harding, Kaczynski dan Wood (2005) state that Blended Learning is the learning that is integrated face to face traditional learning and distance learning (online) with variety of communication that can be used by lectures and students. The implementation of Blended learning enable the use of online learning especially web based without leaving face to face activity. In addition, MacDonald (2008) states that blended learning is assosiated with using online media in learning, and in the same time is conducting face to face learning with conventional. Based on expert's opinion above, the researcher formulate the blended learning formulation on the school curriculum studies that is not only integrate traditional learning with distance learning as proposed by Harding, Kaczynski, Wood and Mac Donald. But formulating 


\section{THE EFFECTIVENESS OF BLENDED LEARNING STRATEGY FORMULATION ON IMPLEMENTING CURRICULUM IN DEPARTMENT OF CURRICULUM AND EDUCATIONAL TECHNOLOGY AT PADANG STATE UNIVERSITY}

the number of material presentation through online learning and face-to-face learning based on the characteristics of the subject material. The development of product in the form of blended learning strategy formulation should be evaluated to determine the practicality after it is implemented in the School Curriculum Studies subject.

\section{Research methods}

The type of research was the development research. The model used was ADDIE model developed by Reiser and Molenda (Bown \& Green, 2011; Goddess, 2009. The model has five stages, namely Analysis, Design, Development, Implementation, and Evaluation. In the second year it hds reached the stage of implementation to know the effectiveness of strategy formulation blended learning on School Curriculum subject. The process of testing the effectiveness begin with implementing the learning process by using the formulation of blended learning strategy on school curriculum subject toward small groups was three people, middle group was 7 people and large group was 40 people. Then the students' learning outcome who used blended learning strategy formulation was compared to students who attended face-to-face lectures

\section{Result}

Based on the development and validation of formulation blended learning strategy, was $62.5 \%$ of online learning and formulation face-to-face meetings was $37.5 \%$. The implementation at face to face meetings using the course handout distributed by lecturers and online learning by using media learning website (www.kajiankurikulum.com). The test of effectiveness of the strategy formulation blended learning course on the School Curriculum Studies was conducted on students who were active and registered in semester from January to June 2015. The effectiveness is an activity to review whether the activity that has been done achieve the goals. After, the product is produced and tested in the learning activities it is necessary to evaluate the results of learning to see the achievement of the formula strategy implementation of blended learning in curriculum implementation. The phase of effectiveness is the last stage in the development model, namely the evaluation phase of the product that has been developed

The effectiveness was obtained from the students' final grades, namely recapitulation of weekly assignments, midterms, final assignments and the grade of students attend lectures during the semester. The final task is the replacement for the semester final exams that are done by giving final project to the students to determine the mastery level and depth ability to analyze the basic education curriculum. The final task was sent to lecturer's e-mail in accordance with the schedule. The lecturer e-mail was abnahidayati@pps.unp.ac. The students' assignment that was sent to that address, then downloaded, read and assessed according to the category of assessment by the lecturer. The results of assessment of student assignments can be seen in appendix 6. The appendix 6 lists the grade of class A with section code was 201420040037 that conducted face to face learning without combined with online learning, and class B with the section code was 201420040039 that conducted lecture by combining face-to-face meetings with online learning. Then, this value was analyzed and both will be compared for significant prove of the effectiveness of the implementation of blended learning strategy formulation that has previously been formulated for School Curriculum subjects. 


\section{THE EFFECTIVENESS OF BLENDED LEARNING STRATEGY FORMULATION ON IMPLEMENTING CURRICULUM IN DEPARTMENT OF CURRICULUM AND EDUCATIONAL TECHNOLOGY AT PADANG STATE UNIVERSITY}

Based on the value that has been obtained, there is the distribution of the students' data values in school curriculum subject class A with code 201420040037 that was conducting face to face lectures without combination with online learning

Table 1. Distribution of student grades on section 201420040037

\begin{tabular}{|c|c|c|c|c|c|c|c|c|}
\hline $\begin{array}{c}\text { Interval } \\
\text { class }\end{array}$ & $\begin{array}{c}\text { Upper limit } \\
\text { Lower } \\
\text { limit }\end{array}$ & $\begin{array}{c}\text { Middle } \\
\text { Scor } \\
\text { (x) }\end{array}$ & $\begin{array}{c}\text { Fre- } \\
\text { quency } \\
\text { (f) }\end{array}$ & $\%$ & $\begin{array}{c}\text { Frequency } \\
\text { Comulatif } \\
\text { (cf) }\end{array}$ & (\%) & $(\mathrm{x}-\mathrm{M})$ & $\begin{array}{c}\mathrm{f}(\mathrm{x}- \\
\mathrm{M})^{2}\end{array}$ \\
\hline $68-74$ & $67,5-74,5$ & 71 & 16 & 40,00 & 40 & 100 & -2 & 91 \\
\hline $75-81$ & $74,5-81,5$ & 78 & 21 & 52,50 & 24 & 60 & 5 & 446 \\
\hline $82-88$ & $81,5-88,5$ & 85 & 3 & 7,50 & 3 & 7,5 & 12 & 404 \\
\hline Jumlah & & & 40 & 100 & & & & 942 \\
\hline
\end{tabular}

There is a frequency distribution class A grade s with code 201420040037 conducting lectures face to face meetings with the usual way

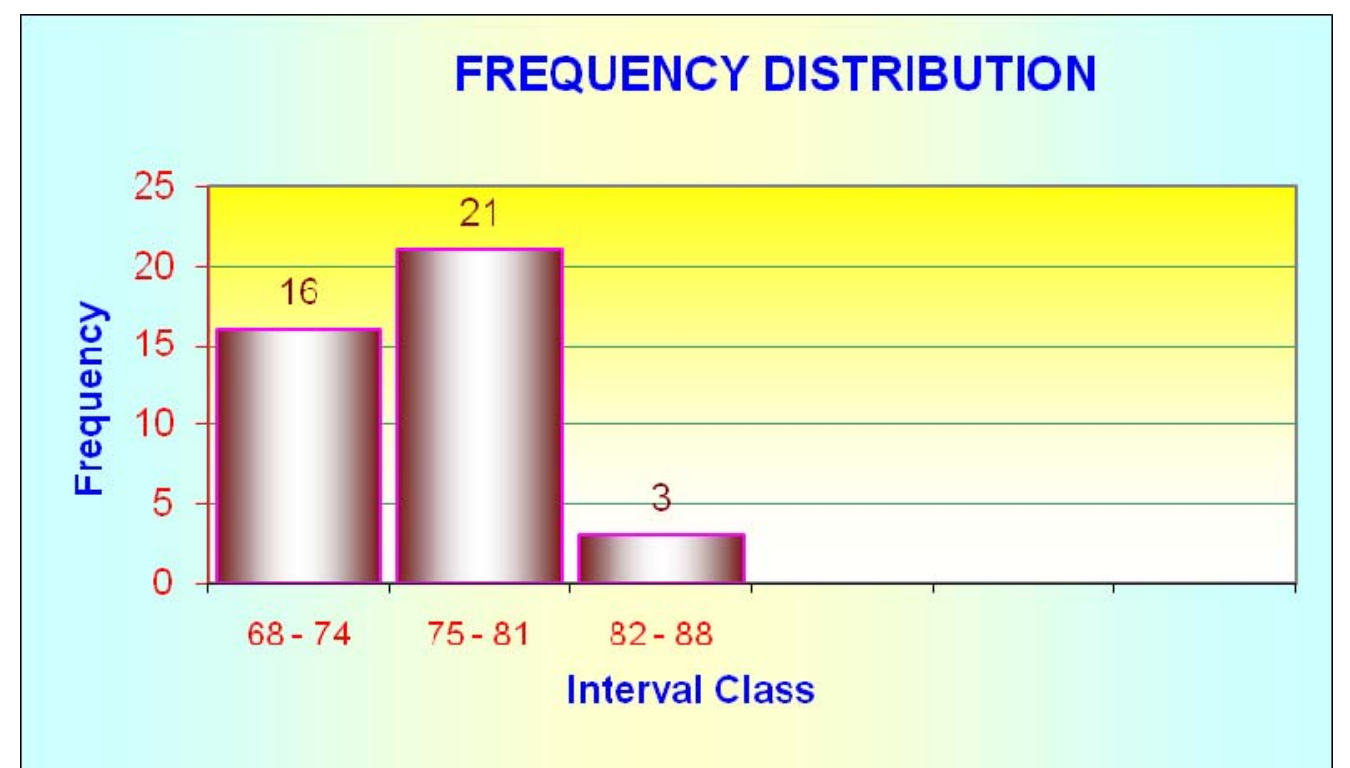

Figure 1. Frequency distribution of students' grade in section code 201420040037

Then, class B with code 201420040039 conducting lectures by combining face-to-face meetings with online learning. Here the distribution of the data value of students in the School Curriculum subject class B

Table 2. Distribution of student grades on section 201420040039 


\section{THE EFFECTIVENESS OF BLENDED LEARNING STRATEGY FORMULATION ON IMPLEMENTING CURRICULUM IN DEPARTMENT OF CURRICULUM AND EDUCATIONAL TECHNOLOGY AT PADANG STATE UNIVERSITY}

\begin{tabular}{|c|c|c|c|c|c|c|c|c|}
\hline $\begin{array}{c}\text { Interval } \\
\text { class }\end{array}$ & $\begin{array}{c}\text { Upper } \\
\text { limit } \\
\text { Lower } \\
\text { limit }\end{array}$ & $\begin{array}{c}\text { Midlle } \\
\text { Score } \\
(\mathrm{x})\end{array}$ & $\begin{array}{c}\text { Frequency } \\
\text { (f) }\end{array}$ & $\%$ & $\begin{array}{c}\text { Frek } \\
\text { Kum } \\
(\mathrm{cf})\end{array}$ & $\begin{array}{c}\text { Frek } \\
\text { Kum } \\
(\%)\end{array}$ & $(\mathrm{x}-\mathrm{M})$ & $\begin{array}{c}\mathrm{f}(\mathrm{x}- \\
\mathrm{M})^{2}\end{array}$ \\
\hline $64-69$ & $\begin{array}{r}63,5- \\
69,5\end{array}$ & 66,5 & 4 & 10,00 & 40 & 100,00 & -9 & 355 \\
\hline $70-75$ & $\begin{array}{r}69,5- \\
75,5\end{array}$ & 72,5 & 14 & 35,00 & 36 & 90,00 & -3 & 163 \\
\hline $76-81$ & $\begin{array}{r}75,5- \\
81,5\end{array}$ & 78,5 & 18 & 45,00 & 22 & 55,00 & 3 & 120 \\
\hline $82-87$ & $\begin{array}{r}81,5- \\
87,5\end{array}$ & 84,5 & 4 & 10,00 & 4 & 10,00 & 9 & 295 \\
\hline Jumlah & & & 40 & & & & & 933 \\
\hline
\end{tabular}

There is a frequency distribution grades class B with code 201420040039 conducting lectures by combining face-to-face meetings with online learning .

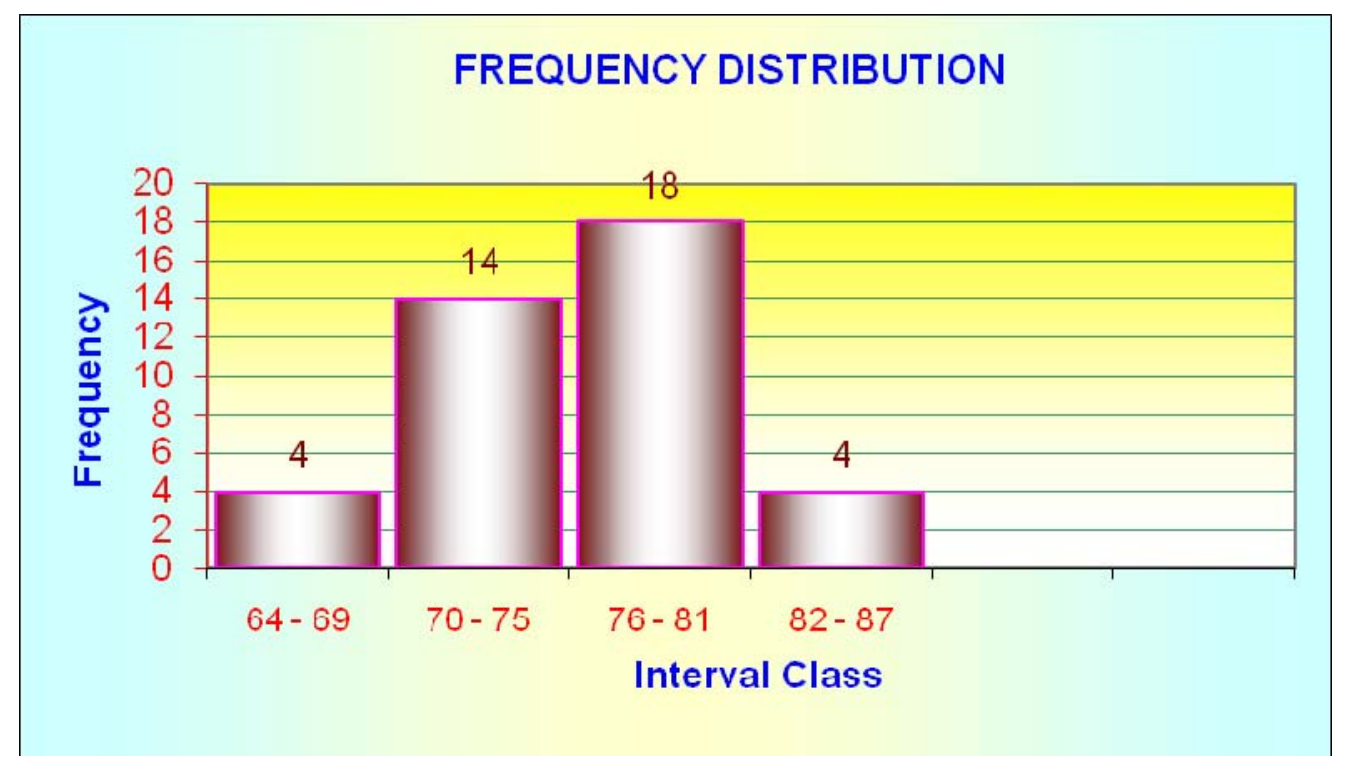

Figure 2. Frequency Distribution of student values on section 201420040039

Then, a class B with a section code 201420040039 was the class that is conducting lectures by combining face-to-face meetings with online learning. The table below is the distribution of the data of student values in the School Curriculum Studies course class B.

Before t test analysis is done on students' value, the researcher has done the distribution test of the data that is test of normality and homogeneity test.

\section{a. Normality test}

Based on data from study results that have been obtained then the normality test was done. The research team conducted an analysis of normality test using SPSS 20. The results of 


\section{THE EFFECTIVENESS OF BLENDED LEARNING STRATEGY FORMULATION ON IMPLEMENTING CURRICULUM IN DEPARTMENT OF CURRICULUM AND EDUCATIONAL TECHNOLOGY AT PADANG STATE UNIVERSITY}

the processing the data showed that both of the data are normal. From the analysis of the data obtained by the value of Shapiro-Wilk class $A$ is 0.0607 . The value is greater $(>)$ than 0.05 , which means the data is normally distributed. While the results of the analysis of the data obtained by the value of Shapiro-Wilk class B is 0.456 . The value is greater $(>)$ than 0.05 , which means the data is normally distributed. After having both of data is the normal distribution,hence it can be done $t$ test analysis.

\section{b. Homogeneity test}

Homogeneity test is done to see if the data classroom learning outcomes that conducted lecturing by combining face-to-face meetings with online learning and classroom learning outcome data that conducted lectures only did with face to face meetings have variances homogeneous or not. In the homogeneity test used test F. After calculating the second class of the samples, the result showed that $F$ arithmetic $<F$ table, namely $1,006<2$. That means the two classes come from a homogeneous population have the variant.Uji $t$

\section{c. T test}

After conducting tests of normality and homogeneity of the final grades of students in the School Curriculum Studies subjects, normal and homogeneous data can be done test to compare two values. T test analysis was performed using SPSS 20.

Based on data analysis at the level of significance values of 0.05 is 0.032 . This means that the significance value $<0.05$, that means there is a significant difference between the results of learning to use a blended learning strategy formulation with face to face meetings on the implementation of the curriculum in the Department of Curriculum and Educational Technology. $\mathrm{T}$ test results showed that the blended learning strategy formulation in the implementation of the curriculum in the subject of the school curriculum study is effectively.

\section{Discussion}

According Akker (1999) effectiveness refers to the level of experience and outcomes of interventions intended destination. The effectiveness blended learning strategy formula in the implementation of the curriculum in the Department of Curriculum and Educational Technology seen from the quality of learning outcomes, attitude, and motivation of learners. On this course, the quality of student views of weekly assignments, midterms, final exams and participation of students in the lecture. After the prepared formula has a valid and practical, then the implementation process is continued until the end of the semester to obtain students' final grades. Hubbard (1983) proposes nine criteria for assessing the effectiveness of product development. His first criteria are the cost. Costs had to be judged by the results achieved with the use of the media. Other criteria are the availability of facilities such as electricity, compatibility with class size, conciseness, the ability to be changed, the time and effort to prepare, the effect that is appeared, the complexity and the latter is usability. The more the learning objectives achieved more effective strategies used.

For example, the goals of study the school curriculum are after attending this course the students are able to examine the structure of Curriculum 2013, and KTSP and the students are able to see the difference with the 2004 curriculum and the linkages between the National Education objectives, competence, standards and basic competencies. Understanding the new 


\section{THE EFFECTIVENESS OF BLENDED LEARNING STRATEGY FORMULATION ON IMPLEMENTING CURRICULUM IN DEPARTMENT OF CURRICULUM AND EDUCATIONAL TECHNOLOGY AT PADANG STATE UNIVERSITY}

approach in the implementation of the curriculum and syllabus examine the curriculum in 2013 and KTSP and look into compliance with the syllabus teaching materials that allow the preparation of teaching materials as part of self-employment and implement the teaching profession. When the goal is achieved, the blended learning formulation can be applied effectively. The achievement of these goals of the final grade students can be seen as an accumulation of $15 \%$ duty / participation of students in the lecture, $20 \%$ of student papers weekly assignments, $25 \%$ of midterms and $40 \%$ of the final project of the semester.

Furthermore, the effectiveness of the implementation of blended learning strategy formulation in the implementation of curriculum is also supported by the goal of this formulation. Based on the background of the problems of this study, the application of blended learning strategy formulation that is appropriate to implement the curriculum in accordance with the development of science and technology it has not been found yet. Curriculum implementation activities conducted so far have not accommodated the needs of students towards science. Undiscovered design curriculum implementation that involves learning face to face and online.

The results of formulation in implementation of blended learning strategy formulation that is valid, practical and effective can be utilized in implementation of the curriculum 1 in higher quality and functional for students. Due to the implementation of blended learning strategy is not to be conducted by 50:50 (eight online meetings and eight face to face meetings), but the formulation of the strategy was formulated by the analysis of the needs of each subject. With this research, more specifically it can be said that the implementation of the curriculum in the subject of study curriculum that applies more interesting, participatory, active and effective.

\section{Conclusion}

1. Based on the research process, it can be concluded that: 1. Formulation of blended learning strategy in implementing curriculum in the Department of Curriculum and Educational Technology was formulated for School Curriculum Studies courses online learning formula about $62.5 \%$ and formula of face to face meetings about $37.5 \%$.

2. The formulation of blended learning strategies in implementing the curriculum in the Department of Curriculum and Educational Technology is effective when compared to classes that do not combine face-to-face meetings with online learning.

\section{Acknowledgement}

An attempt to assess the effectiveness of the formulation of strategies for the application of blended learning in courses of study school curriculum is a challenging job, because learning in two worlds, the real world and the virtual world. In the implementation process of the application of blended learning strategy formulation, the researcher always involves various circles to discuss, such as students and lecturers of faculty the department of Curriculum and Educational Technology. Thus contributions that they provide without mentioning names one by one, the researcher would like to thank. 


\section{THE EFFECTIVENESS OF BLENDED LEARNING STRATEGY FORMULATION ON IMPLEMENTING CURRICULUM IN DEPARTMENT OF CURRICULUM AND EDUCATIONAL TECHNOLOGY AT PADANG STATE UNIVERSITY}

\section{References}

Alwen Bentri. 1993. Implementasi Kurikulum di SD Kecil dan Faktor-faktor yang Mempengaruhinya. Tesis tidak diterbitkan. Bandung: Program Pascasarjana Institut Keguruan dan Ilmu Kependidikan

Akhmad Sudrajat. 2008. Pendekatan, Strategi, Metode, Teknik dan Model Pembelajaran.http://akhmadsudrajatwordpress.com/2008/09/12/pendekatan-strategimetode-teknik-dan-model-pembelajaran/. Diakses 1 Mei 2012

Akker, Jan Van Den. 1999. Design Approaches and Tools in Education and Training. Dordrecht:Kluwer Academic Publisher .2006. Gravemeijer, Koeno. McKenney, Susan. and Nieveen, Nienke. 2006. Educational Design Research. Netherlands

Bersin, Josh. 2004. The Blended Learning Book; Best Practices, Proven Methodologies and Lessons Learned. United Stated: John Wiley \& Sona, Inc.

Brown, Abbie \& Green Timpthy. D. 2011. The Essentials of Instructional Design; Connecting Fundamental Principles with Process and Practice. Boston: Pearson Education, Inc.

Dewi Salma Prawiradilaga. 2009. Prinsip-prinsip Desain Pembelajaran. Jakarta: Kencana

Kaufman, Roger \& English, Fenwick W. 1979. Needs Assessment. New Jersey: Educational Technology Publication, Inc.

MacDonald, Janet. 2008. Blended Learning and Online Tutoring; Planning Learner Support and Activity Design. England: GOWER HOUSE

Munir. 2009. Pembelajaran Jarak Jauh Berbasis Teknologi Informasi dan Komunikasi. Bandung: AlfaBeta

Nieveen, Nienke. 1999. Prototyping to Reach Product Quality. Dordrecht:Kluwer Academic Publisher

Redaksi Sinar Grafika. 2006. Peraturan Pemerintah no 19 tahun 2005 tentang Standar Nasional Pendidikan. Jakarta: Sinar Grafika

Plomp, Tjeerd \& Nieveen, Nienke. 2010. An Introduction to Educational Design Research. Proceeding of the seminar conducted at the East China Normal University, Shanghai (China), November 23-26, 2007

Prayitno. 2014. Pembelajaran melalui Pelayanan BK di Satuan Pendidikan. Padang: urusan Bimbingan dan Konseling Fakultas Ilmu Pendidikan Universitas Negeri Padang

Punaji Setyosari. 2013. Metode Penelitian Pendidikan dan Pengembangan. Jakarta: Kencana

Rusman, Deni Kurniawan dan Cepi Riyana. 2011. Pembelajaran Berbasis Teknologi Informasi dan Komunikasi; Mengembangkan Profesonalitas Guru. Jakarta: Rajawali Press

Smaldino, Sharon E., Lowther, Deborah L. dan Russell, James D. 2008. Instructional Technology and Media for Learning. New Jersey: Pearson Education

Thorne, Kaye. 2003. Blended Learning: How to Integrate Online and Traditional Learning. Great Britain and United States:British Library

Tim Pengembang MKDP Kurikulum dan Pembelajaran. 2011. Kurikulum dan Pembelajaran. Bandung: Rajawali Press 